\title{
Alkali-treated Wheat Gluten Cross-linked with Sodium Alginate as a Bio-based Wood Adhesive for Interior Grade Particleboard
}

\author{
Ajith K. A. Gedara, ${ }^{\mathrm{a}}$ Iva Chianella, ${ }^{\mathrm{a}}$ Debabrata Bhattacharyya, ${ }^{\mathrm{a}}$ Jose L. Endrino, ${ }^{\mathrm{b}}$ and \\ Qi Zhang ${ }^{\text {b,c }}$
}

\begin{abstract}
A bio-based wood adhesive formulation free of formaldehyde and made from alkali-treated wheat gluten (WG) and sodium alginate (SA) was developed. Its formulation was optimised, and it was characterised by Fourier Transform Infrared (FT-IR) spectroscopy. The bio-adhesive was utilized to make particleboards both with virgin wood particles and recycled wood particles. A dry bio-adhesive content of $35 \%(\mathrm{w} / \mathrm{w})$ was used to make samples with both type of particles. Single-layer samples of $10 \mathrm{~mm}$ thickness were obtained using wood particles of $1 \mathrm{~mm}$ (both virgin and recycled). These samples then were subjected to 3-point bending tests. Whereas the bending strength of samples made with recycled wood particles was $18.09 \mathrm{~N} / \mathrm{m}^{2}$ and therefore satisfied Type 18 of the Japanese industrial standards (JIS A 5908:2015), the bending strength of the samples made with virgin wood particles was $8.08 \mathrm{~N} / \mathrm{m}^{2}$ and satisfied 'Type 8 Base particleboard Decorative particleboard' of the Japanese standards. The density of particleboard samples made from recycled wood particles was $916 \mathrm{~kg} / \mathrm{m}^{3}$, while that of samples made from virgin wood particles was $732 \mathrm{~kg} / \mathrm{m}^{3}$. The alkali-treated WG and SA bio-adhesive has the potential to be used to re-manufacture particleboards, which can then be recycled and not disposed in landfills.
\end{abstract}

Keywords: Sodium alginate; Wheat gluten; Bentonite; Particleboard

Contact information: a: School of Aerospace, Transport and Manufacturing, Cranfield University, Cranfield, Bedfordshire MK43 OAL United Kingdom; b: BCMaterials, Basque Center for Materials, Applications and Nanostructures, UPV/EHU Science Park, Leioa 48940 Spain; c: IKERBASQUE, Basque Foundation for Science, Plaza Euskadi, 5, Bilbao 48009 Spain;

* Corresponding author: Qi Zhang, qi.zhang@bcmaterials.net

\section{INTRODUCTION}

Formaldehyde emissions released by furniture made using synthetic wood adhesives are toxic for human beings due to their carcinogenic nature (WHO 2004). Although the wood itself emits formaldehyde, its contribution is minor in comparison to the emissions due to the presence of synthetic adhesives (Salem and Böhm 2013). Formaldehyde emissions from wood furniture can be minimized by replacing the synthetic adhesives with biobased adhesive formulations during the manufacturing process. Doing so would ultimately optimize indoor air quality (Zhang et al. 2018). In this study, sodium alginate, wheat gluten, and bentonite were selected as raw materials to develop a new wood bioadhesive formulation. The bio-based binder of the alkali-treated wheat gluten and sodium alginate was then combined with virgin wood particles and recycled wood particles to make particleboards. The resulting wood products were then characterized to evaluate whether they satisfied industrial standards. 
The basic raw material for the production of sodium alginate (SA) is brown algae (Javed et al. 2015). Alginates are unbranched polysaccharides and complex carbohydrate polymers derived from brown seaweeds (Pawar and Edgar 2012). Tens of millions of tons (according to frozen weight) of seaweed is harvested both offshore and onshore (Nayar and Bott 2014). Alginates are used in industrial applications due to their gelling, viscosifying, and stabilizing properties (Draget et al. 2004). Sodium alginate has been used as a biodegradable additive in the papermaking industry in conjugation with polyamideamineepichlorohydrin to increase the mechanical properties of the recycled fibers (Bai et al. 2017). When used as a structural scaffold, SA is usually blended, modified, or copolymerized with other biopolymers (Foroughi et al. 2018).

The chemical structure of SA, depicted in Fig. 1, shows that when SA is dissolved in water, it is able to react with the hydroxyl groups in the wood cell walls.

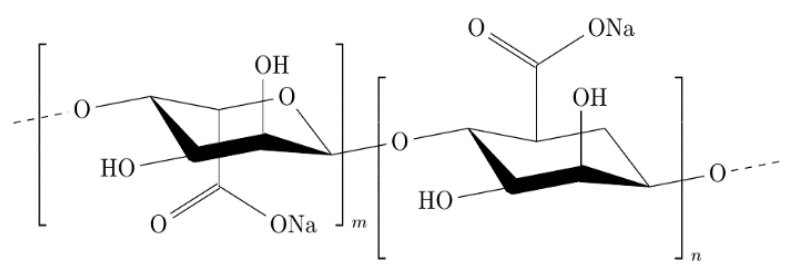

Fig. 1. Chemical structure of a sodium alginate molecule (Homayouni et al. 2007; Foroughi et al. 2018)

Alkaline bentonite binder has been used in roasted-pellet production (Gasik et al. 2009). The addition of bentonite has been shown to enhance the falling strength and compression strength of green pellets (Liu et al. 2017). By considering these factors, bentonite was selected for this study as an additive for the bio-based wood adhesive formulation. Wheat gluten (WG) is the rubbery mass that remains after the wheat dough is water washed to remove starch granules (Wieser 2007). Wheat gluten is an abundant protein source that can be obtained as a by-product from wheat starch processing (Nordqvist et al. 2013; Ferdosian et al. 2017). It consists of acid-dispersible glutenins (which have elastic properties) and alcohol soluble gliadins (which have viscous properties) (Hemmilä et al. 2017). Wheat gluten complex mixtures comprise of $80 \%$ wheat proteins, with the rest being lipids, polysaccharides, and minerals (Ferdosian et al. 2017; Hemmilä et al. 2017). It has been shown that rigid bio-based materials can be made using WG via high-temperature compression (Jansens et al. 2013b). In addition, WG can be blended with other polymers at high temperatures in order to manufacture bioplastics (Langstraat et al. 2015).

Bio-based adhesives can be made using WG due to its film-forming ability and its thermoplastic properties. Wheat gluten adhesives have been used to produce pressuresensitive medical bandages and adhesive tapes (Day et al. 2006). As an elastomeric protein source, wheat gluten possesses cohesive and unique viscoelastic properties showing the suitability for material applications such as wood adhesives (Nordqvist et al. 2013; Mathias et al. 2016). The proteins derived from gluten can be divided into two groups (or subunits) according to their molecular weight, i.e., high-molecular-weight (HMW) and lowmolecular-weight (LMW) glutenin subunits (Khelifi and Branlard 1992; Schalk et al. 2017). 


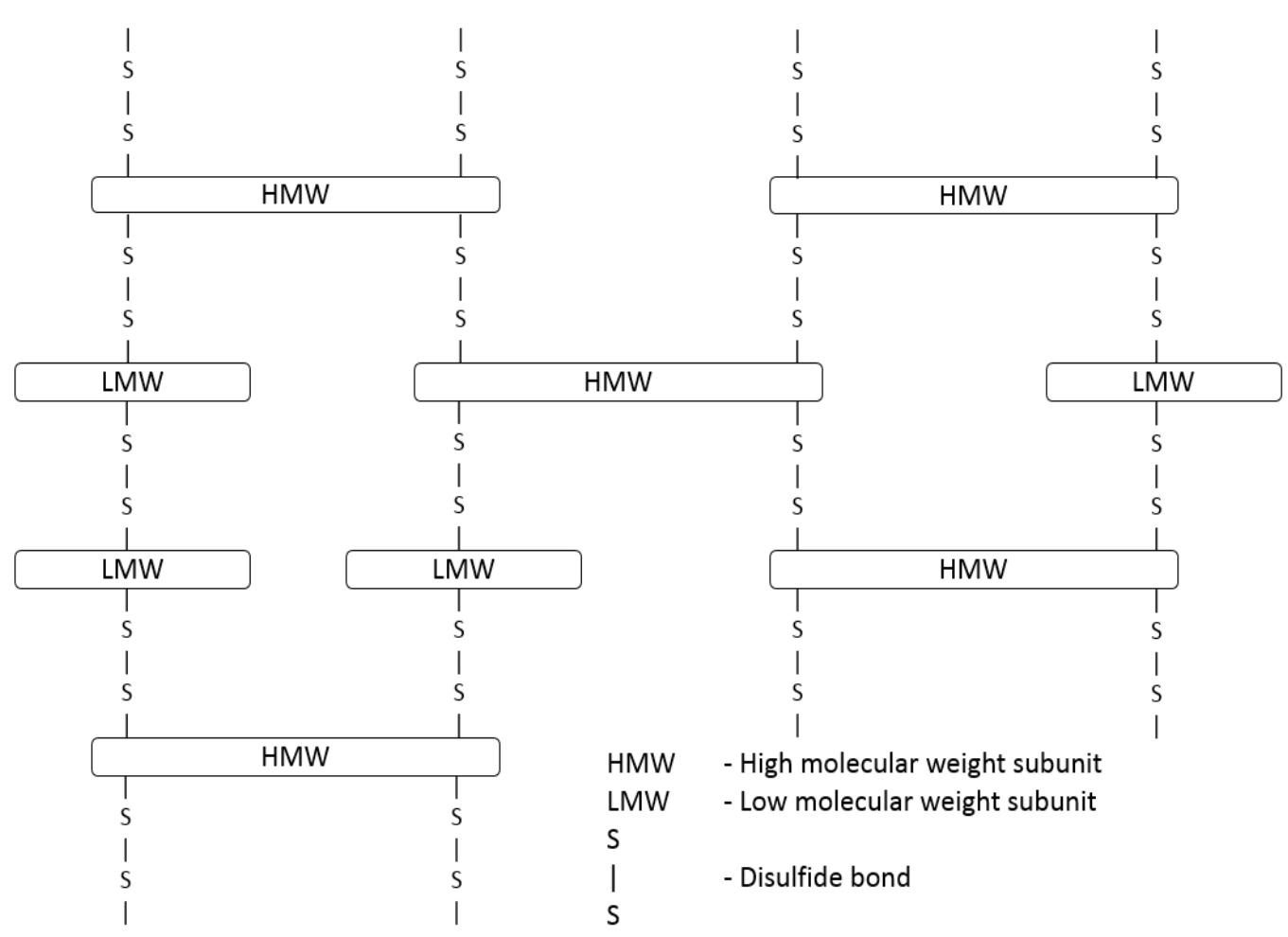

Fig. 2. A structural model for wheat gluten (Shewry et al. 2000; Lamacchia et al. 2014)

In the WG structure, the HMW subunits and LMW subunits are connected with disulfide bonds (Fig. 2). Wheat gluten consists of hundreds of proteins, and these proteins are present as monomers, oligo, or polymers linked via inter-chain disulfide bonds (Shewry et al. 2000; Wieser 2007; Lamacchia et al. 2014). The solubility of these proteins progressively increases with alkaline $\mathrm{pH}$ values (Du et al. 1994). In fact, the degradation of disulfide bonds can be performed by adding $0.2 \mathrm{M}$ of $\mathrm{NaOH}$ at a temperature of $25^{\circ} \mathrm{C}$ (Florence 1980). Whereas disulfide bonds seem to dominate the crosslinking at a temperature of $130{ }^{\circ} \mathrm{C}$, the non-disulfide bonds contribute to the protein network at a temperature of $150{ }^{\circ} \mathrm{C}$ (Jansens et al. 2017). While WG is not dispersible in water due to its high amount of non-polar amino acids, it is dispersible in the presence of either alkalis or acids, as its isoelectric point is 7.3 (Khosravi et al. 2011; Hemmilä et al. 2017). It has been reported in literature that a mixture of $\mathrm{WG}$ and $0.2 \mathrm{M}$ of $\mathrm{NaOH}$ as a wood adhesive applied on wood panels and heated to a temperature of $130{ }^{\circ} \mathrm{C}$ for $15 \mathrm{~min}$ under a pressure of $0.7 \mathrm{MPa}$, provided an optimum bond line thickness and a high bond strength of 7.07 MPa (Somord et al. 2014).

Wheat gluten mixed with starch (1:1 ratio), grafted with methylmethacrylate, crosslinked with citric acid, and nanofilled with $\mathrm{TiO}_{2}$ has exhibited excellent thermal stability, water-resistance, and mechanical properties (Baishya et al. 2018). In addition, WG can be blended with synthetic wood adhesives. In order to improve the physical properties, e.g. water absorption and thickness swelling, of high-density particleboard using reeds instead of wood particles, $80 \%$ of the WG was modified with ureaformaldehyde resin alone as well as with the addition of $1 \%$ and $2 \%$ boric acid as a fungicide. The results showed that the mechanical properties, e.g., the modulus of rupture, modulus of elasticity, and internal bond strength, did not change with the addition of boric acid (El-Wakil et al. 2007). On the contrary, the addition of a small proportion of an 
isocyanate to hydroxymethylated or glyoxalated hydrolyzed gluten proteins yielded an improvement in the mechanical properties of the adhesive (Lei et al. 2010).

The addition of triacetin into a phenol-formaldehyde blended WG resin increased the internal bond strength by more than $30 \%$ (Lagel et al. 2015). However, when several particle sizes of alkali-denatured WG were used to prepare WG-protein wood adhesives, the size did not seem to affect the tensile strength (Nordqvist et al. 2010).

A two-steps method for the dispersion of WG in wood, which consisted of drying the glued chips in-between the first and the second addition, has shown to be more beneficial compared to a one-step process (Khosravi et al. 2011). The dispersion concentration, viscosity, and application method were the primary factors that affected the dispersion of wheat gluten into the wood particles. However, the drying temperature, presence of crosslinkers, dispersing agent, and type of wood species seemed to minimally affect the dispersion of wheat gluten into the wood particles (Khosravi et al. 2015). Improved bond strength and water resistance were achieved by using wood adhesives with hydrolyzed WG treated at a temperature of $90^{\circ} \mathrm{C}$ and finally dispersed in $0.1 \mathrm{M}$ of a NaOH water solution (aq) (Nordqvist et al. 2013). Bioproducts, e.g., cups, plates, and boxes, were made using banana fiber-wheat gluten (Nataraj et al. 2018). NaOH solutions had the ability to effectively activate the wood surfaces, yielding strong adhesive bonds (Young et al. 1985).

Today, most of the bio-based wood adhesives that satisfy industrial standards are expensive due to the small-scale production and the high production cost. Wheat gluten as a by-product as well as a co-product in the wheat starch industry is readily available and comparatively less expensive than other bio-based wood adhesives, e.g. tannins (Wang et al. 2009; Jansens et al. 2013a; Ibarra et al. 2016). Compared to WG, smaller amounts of sodium alginate and $\mathrm{NaOH}$ are required to prepare an adhesive mixture. These are readily available and relatively inexpensive. Therefore, their use to prepare adhesive formulations to make interior grade particleboard that satisfies industrial standards is cost effective.

Hence, this research study was carried out to explore the possibility of using alkalitreated wheat gluten crosslinked with sodium alginate as a bio-based wood adhesive to make interior-grade particleboard. The evaluation of the quality of the bio-adhesives was performed by assessing the bending strength and the internal bond strength of the resulting particleboards.

\section{EXPERIMENTAL}

\section{Materials}

Wheat gluten was purchased from Buy Whole Foods Online Ltd (Kent, United Kingdom). Sodium alginate was bought from Sigma Aldrich (St. Louis, MO). Bentonite and $\mathrm{NaOH}$ were bought from Fisher Scientific (Waltham, MA). Kastamonu Entegre (Adana, Turkey) provided $1 \mathrm{~mm}$ virgin wood particles, and $1 \mathrm{~mm}$ recycled wood particles were provided by the French Institute of Technology for Forest-based and Furniture Sectors (Champs-sur-Marne, France).

\section{Preparation of the Samples}

The wood particles of $1 \mathrm{~mm}$ size were dried in a vacuum oven at $130{ }^{\circ} \mathrm{C}$ until the moisture became less than 5\%. A mixture of wheat gluten, sodium alginate, and bentonite were mixed with the wood particles (virgin and recycled particles) while changing various 
parameters such as weight ratios. A NaOH solution (1 M) was sprayed on the mixture until the moisture content was $18 \%$. The mixture was then hot-pressed for $15 \mathrm{~min}$ at a temperature of $150{ }^{\circ} \mathrm{C}$ at a pressure of $1.4 \mathrm{MPa}$ in a hydraulic hot press machine (50 ton press acting on 5" Hydraulic Ram) to make single-layer particleboard sample. The dimensions of the samples prepared were $210 \mathrm{~mm} \times 210 \mathrm{~mm} \times 10 \mathrm{~mm}$. The samples were cut as in Fig. 3 and underwent a 3-point-bend-test and an internal bond (IB) test using the 5/100 kN Instron 5500R Electro-mechanical machine. Samples from three particleboard specimens prepared with the same formulation and conditions were used for the testing. An environmental scanning electron microscope (E-SEM) was used to analyze the composition of the samples.

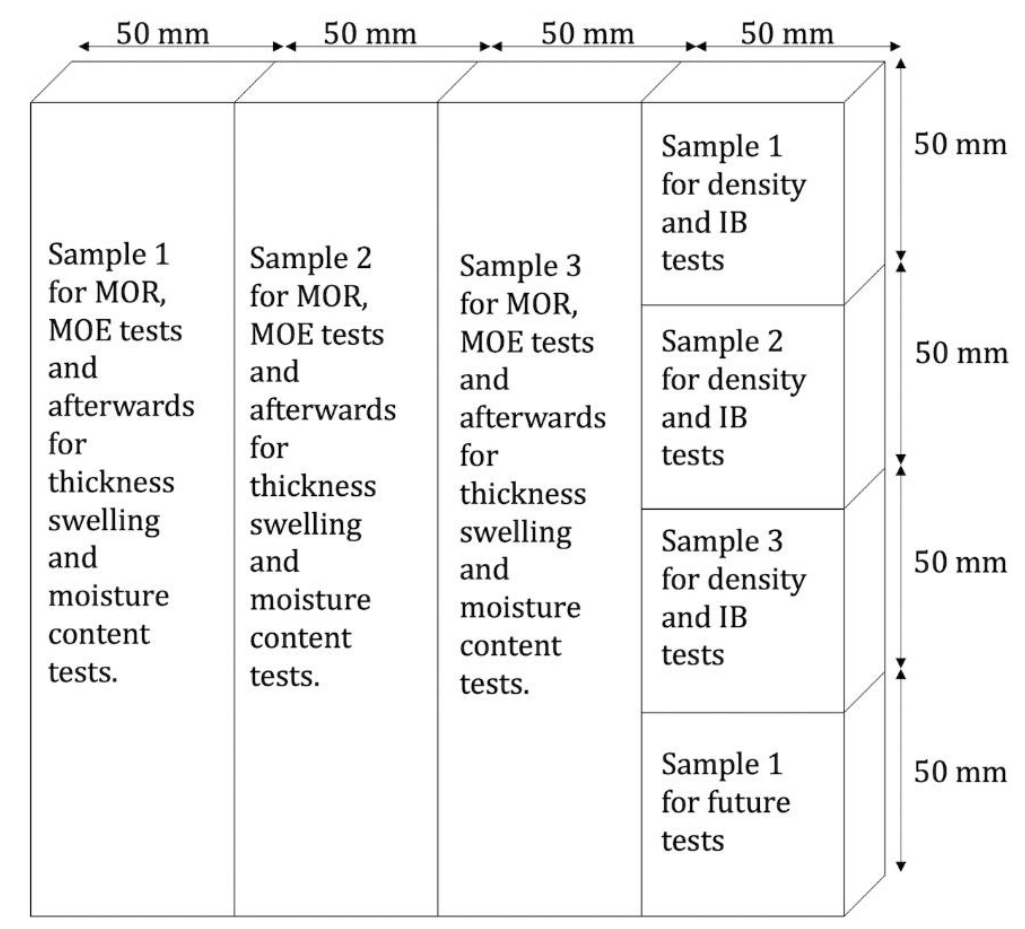

Fig. 3. Cutting to the size of the particleboard for physical and mechanical tests.

\section{Taguchi Design of Experiments}

In order to speed up the optimization of the experimental work, based on the number of variable parameters, e.g. the amount of wood particles, bentonite, sodium alginate, and wheat gluten, a relevant Taguchi orthogonal array was carried out. MINITAB 16 software (Penn State University, University Park, PA) was used to analyze the experimental results. This was helpful in reducing the number of experimental trials necessary for the optimization of the bio-adhesive formulation.

\section{Environmental scanning electron microscopy (E-SEM) analysis}

Samples for the environmental-scanning electron microscope (E-SEM) were prepared by crushing both types of particleboard samples (from virgin and recycled particles using hammer blows) and then gold coating them. A FEI XL30 (Thermo Fisher Scientific, Waltham, MA) machine was used for the analysis. 
$X$-ray diffraction analysis

Prior to the X-ray diffraction analysis, the wheat gluten, sodium alginate, and the appropriate mixture of wheat gluten and sodium alginate samples were mixed with a $\mathrm{NaOH}$ solution $(1 \mathrm{M})$. The amount of the solution used was measured afterwards. The measurements were then performed at room temperature. Oxford Diffraction Xcalibur 2 was used for the X-ray diffraction.

\section{Fourier transform infrared (FTIR) analysis}

Fourier transform infrared spectroscopy (FTIR) was employed to investigate the absorption characteristics of the uncured (alkali-treated WG) and cured samples following synthesis with the aim of identifying the chemical bonds of the compounds and the transformation of their functional groups subjected to curing. The FTIR analysis was performed using an attenuated total reflection (ATR) accessory that allowed the determination of the change in chemical functional groups under different process conditions.

In this experiment, FTIR equipment (Jasco 6200, Easton, MD) was used in conjunction with a PIKE MIRacle ATR accessory. An AZnSe crystal plate was fitted as the ATR sampling interface. Initially, the set up was calibrated in air to reduce the effect of environmental conditions before the sample assessments occurred over a wide wavenumber range (4000 to $550 \mathrm{~cm}^{-1}$ ). The ATR-FTIR absorbance spectra of the uncured and cured resins of the alkali-treated wheat gluten crosslinked with sodium alginate were compared, and the results are shown in Fig. 9.

\section{RESULTS AND DISCUSSION}

\section{Statistical Analysis}

The Taguchi experimental design method was used to evaluate the influence of the compositions of the resin mixture on the modulus of rupture (bending strength), as shown in Table 1. It was found that an increase in the bentonite quantity in the resin reduced the modulus of rupture of the sample, while an increase in the wheat gluten quantity increased it (Fig. 4).

Table 1. Changes of Quantities of Adhesive Components and the Resulted Bending Strength for Taguchi Analysis

\begin{tabular}{|c|c|c|c|c|c|}
\hline $\begin{array}{c}\text { Sample } \\
\text { number }\end{array}$ & $\begin{array}{c}\text { Wood } \\
\text { particles }(\mathrm{g})\end{array}$ & $\begin{array}{c}\text { Bentonite } \\
(\mathrm{g})\end{array}$ & $\begin{array}{c}\text { Sodium } \\
\text { alginate }(\mathrm{g})\end{array}$ & $\begin{array}{c}\text { Wheat } \\
\text { gluten }(\mathrm{g})\end{array}$ & $\begin{array}{c}\text { Bending strength } \\
\left(\mathrm{Nm}^{-2}\right)\end{array}$ \\
\hline 1 & 200 & 45 & 30 & 0 & 4.21 \\
\hline 2 & 200 & 40 & 35 & 0 & 4.43 \\
\hline 3 & 200 & 29 & 57 & 0 & 4.80 \\
\hline 4 & 200 & 43 & 57 & 0 & 5.20 \\
\hline 5 & 200 & 29 & 71 & 0 & 5.88 \\
\hline 6 & 200 & 43 & 71 & 0 & 6.20 \\
\hline 7 & 200 & 31 & 46 & 31 & 6.07 \\
\hline 8 & 200 & 31 & 31 & 46 & 6.65 \\
\hline 9 & 200 & 15 & 62 & 31 & 6.22 \\
\hline 10 & 200 & 15 & 31 & 62 & 7.03 \\
\hline
\end{tabular}




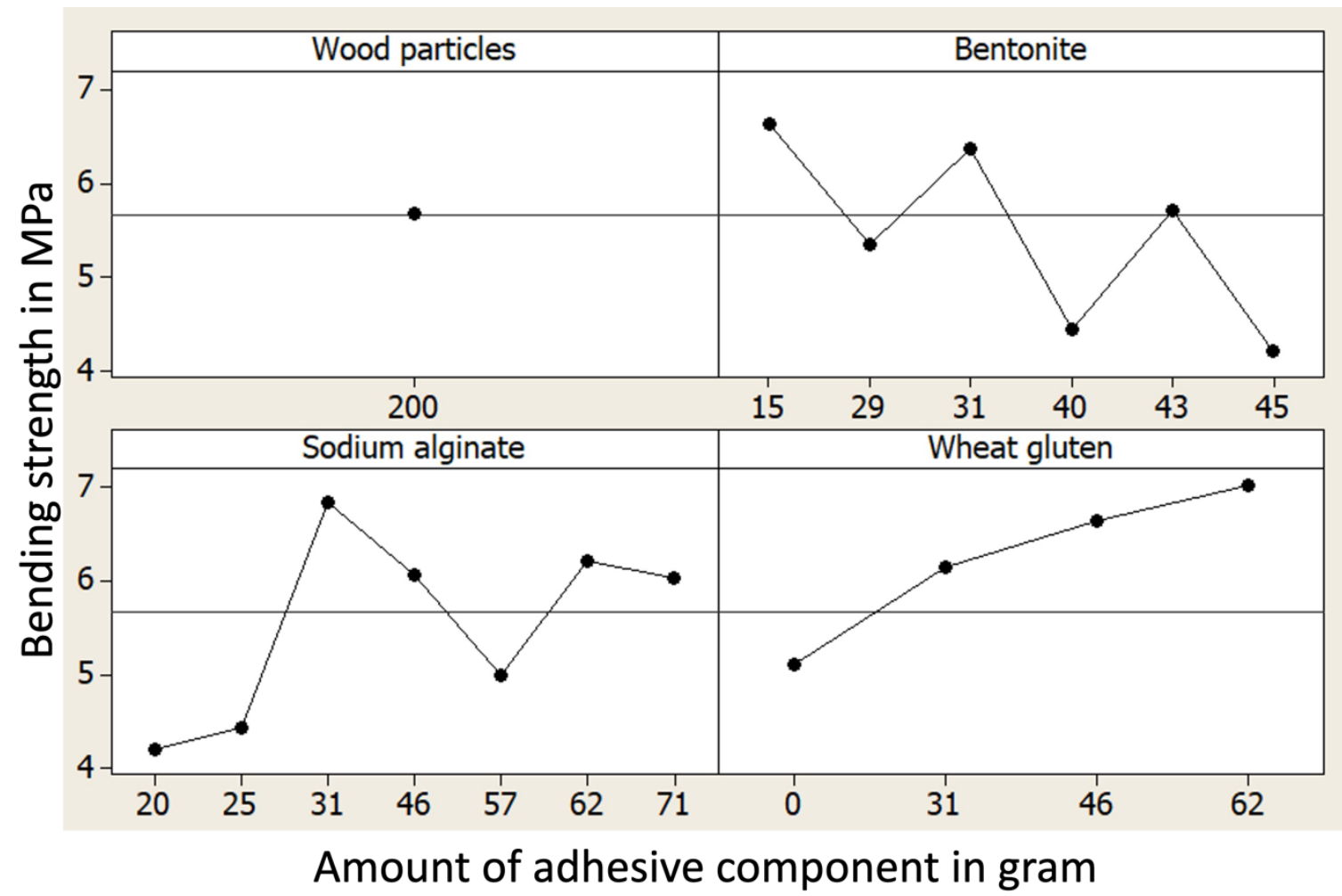

Fig. 4. Taguchi experiment design analysis for the inputs

By considering the Taguchi analysis results, the weight proportions of the wood particles, wheat gluten, and sodium alginate were chosen as $62 \%, 31 \%$, and $7 \%(\mathrm{w} / \mathrm{w})$, respectively, in order to achieve optimal results for the bending strength. A lower amount of sodium alginate was chosen to have better physical properties of the final samples. The necessary concentration of $\mathrm{NaOH}$ was $1 \mathrm{M}$ in order to minimize the agglomeration of the resin mixture.

Environmental scanning electron microscopy (E-SEM) analysis

The optimized adhesive resin was used to prepare particleboards using virgin wood particles and recycled wood-based panel particles. Both particleboards were made from particles of the same size. Increased amounts of $\mathrm{N}$ and $\mathrm{O}$ were observed as shown in Table 2 in the recycled wood particleboard, which was due to the presence of urea-formaldehyde, as observed by the composition analysis of EDX via E-SEM.

Table 2. Elemental Analysis of Samples Made with Virgin Wood Particles and Recycled Wood Particles

\begin{tabular}{|c|c|c|c|c|}
\hline \multirow{2}{*}{ Sample type } & \multirow{2}{*}{$\begin{array}{c}\text { Sample } \\
\text { number }\end{array}$} & $\mathrm{C}$ & $\mathrm{N}$ & Element percentages \\
\cline { 2 - 5 } & 1 & 54.20 & 8.45 & 34.12 \\
\hline \multirow{3}{*}{ Virgin wood particles } & 2 & 56.26 & 5.10 & 37.71 \\
\cline { 2 - 5 } & 3 & 38.20 & $\mathrm{~N} / \mathrm{A}$ & 33.70 \\
\hline \multirow{2}{*}{$\begin{array}{c}\text { Recycled wood } \\
\text { particles }\end{array}$} & 1 & 44.33 & 13.81 & 39.84 \\
\cline { 2 - 5 } & 2 & 45.28 & 12.99 & 40.85 \\
\cline { 2 - 5 } & 3 & 46.77 & 14.32 & 38.36 \\
\hline
\end{tabular}


The wood cell lumens were also observed via E-SEM images of the virgin wood particleboard samples (Fig. 5). However, the lumens were not observed in the particleboards made using recycled wood-based panel particles, which were comparatively higher in density and had different mechanical properties.

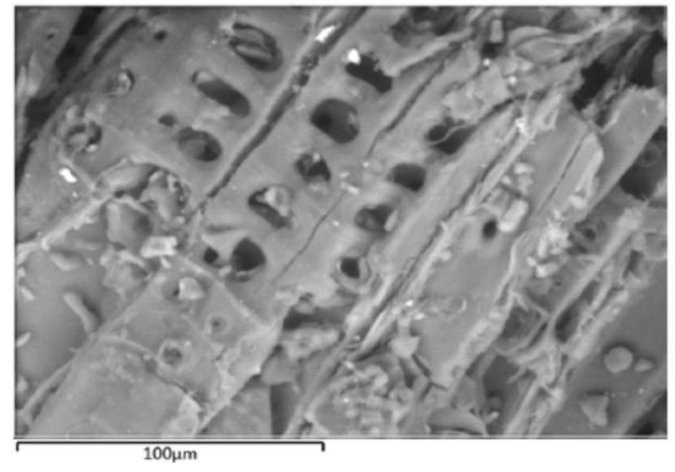

(a) Virgin wood particles

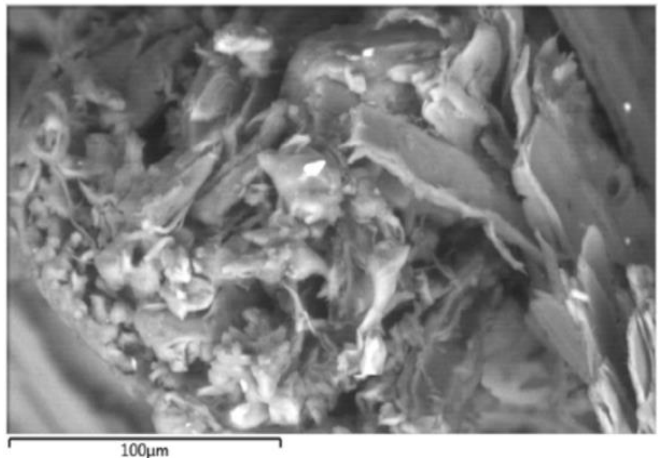

(b) Recycled wood particles

Fig. 5. E-SEM images of the particleboard samples prepared using virgin wood particles and recycled wood-based panel particles

$X$-ray diffraction analysis $(X R D)$

The resin was subjected to XRD analysis to evaluate its crystallinity and compare it to WG and sodium alginate separately. Figure 6 shows their diffraction patterns. The crystallinity indexes (CI) were calculated according to Eq. 1,

Crystallinity Index $=\left[\frac{I_{200}-I_{a m}}{I_{200}}\right] \times 100 \%$

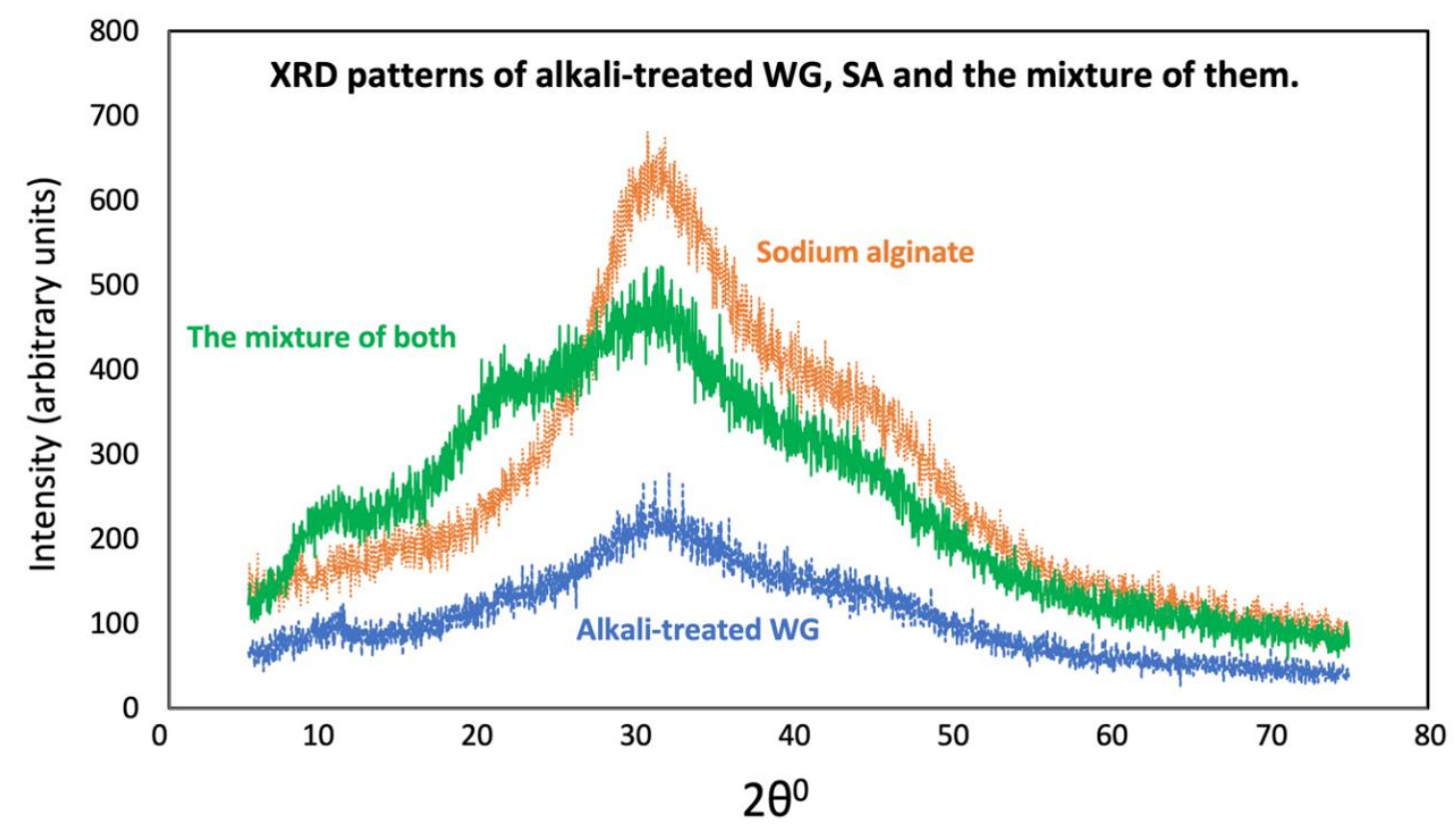

Fig. 6. XRD analysis of the alkali-treated wheat gluten, sodium alginate, and a mixture of both 
where $I_{200}$ is the peak intensity corresponding to the crystalline fraction and $I_{a m}$ is the intensity of the amorphous fraction. Then, the CI were compared by using the diffraction patterns (as shown in Fig. 7).

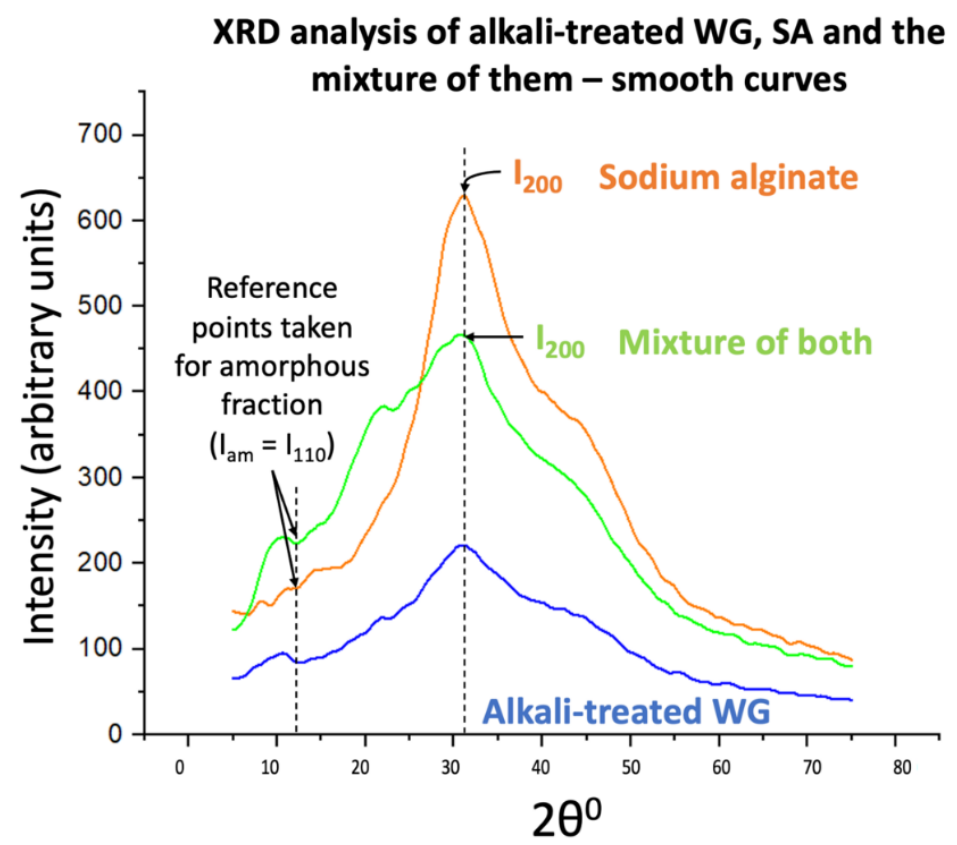

Fig. 7. XRD analysis of alkali-treated wheat gluten, sodium alginate and their mixture using smooth curves taken by using OriginPro2021 software

The crystallinity index of the alkali-treated mixture (WG+SA) was lower than the other tested samples (Table 3). A lower crystallinity index implies a higher bond strength. This shows that the modification of wheat gluten and sodium alginate can increase the strength of the final wood composite (Amini et al. 2019).

Table 3. Crystallinity Indexes of the Samples

\begin{tabular}{|c|c|c|c|}
\hline Sample & $I_{200}$ & $l_{a m}$ & $\mathrm{Cl}(\%)$ \\
\hline WG & 225 & 85 & 62 \\
\hline SA & 632 & 165 & 74 \\
\hline WG + SA & 467 & 225 & 52 \\
\hline
\end{tabular}

Fourier transform infrared (FTIR) analysis

The results of the FTIR analysis of wheat gluten and the cured and uncured alkalitreated wheat gluten crosslinked with sodium alginate resins are shown in Fig. 8 (full range) and Fig. 9 (in detail). The assignment of the peaks is presented in Tables 4 and 5. 


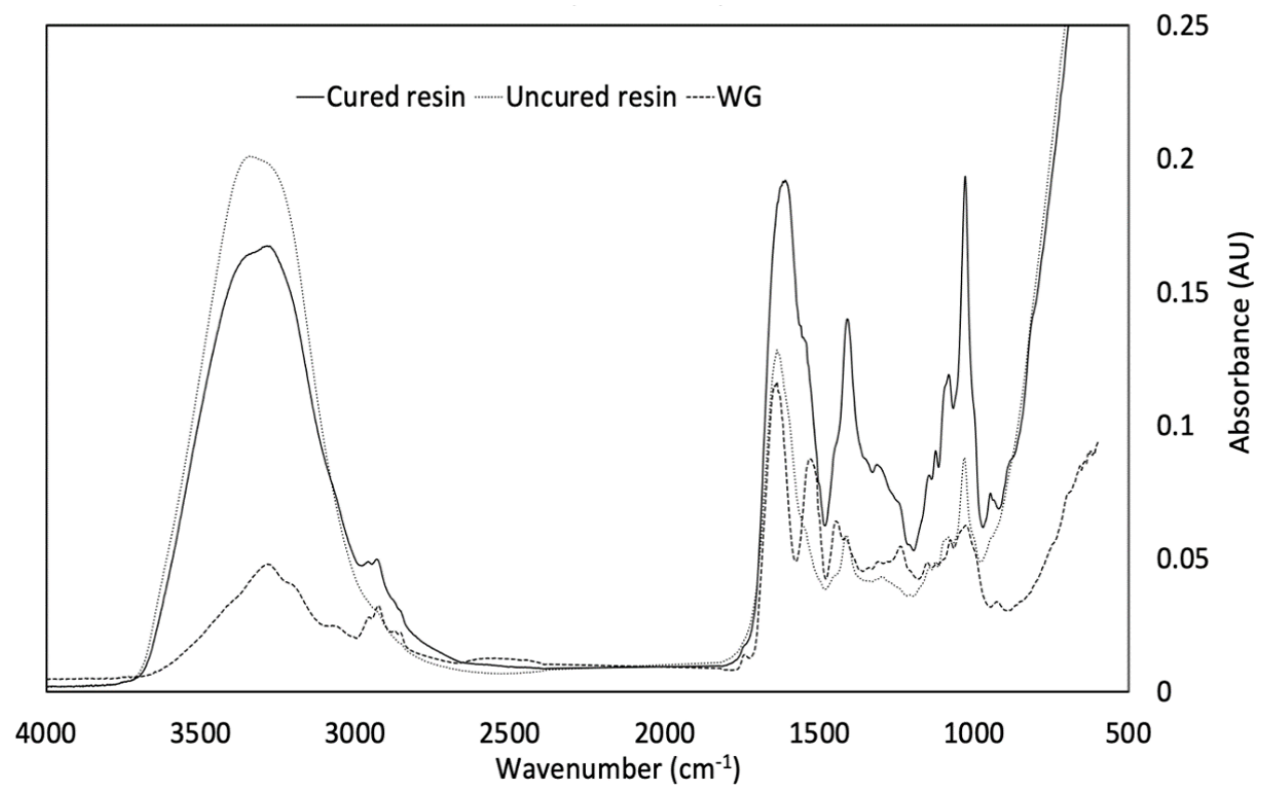

Fig. 8. FTIR analysis of wheat gluten and the alkali-treated cured and uncured resins (full range)

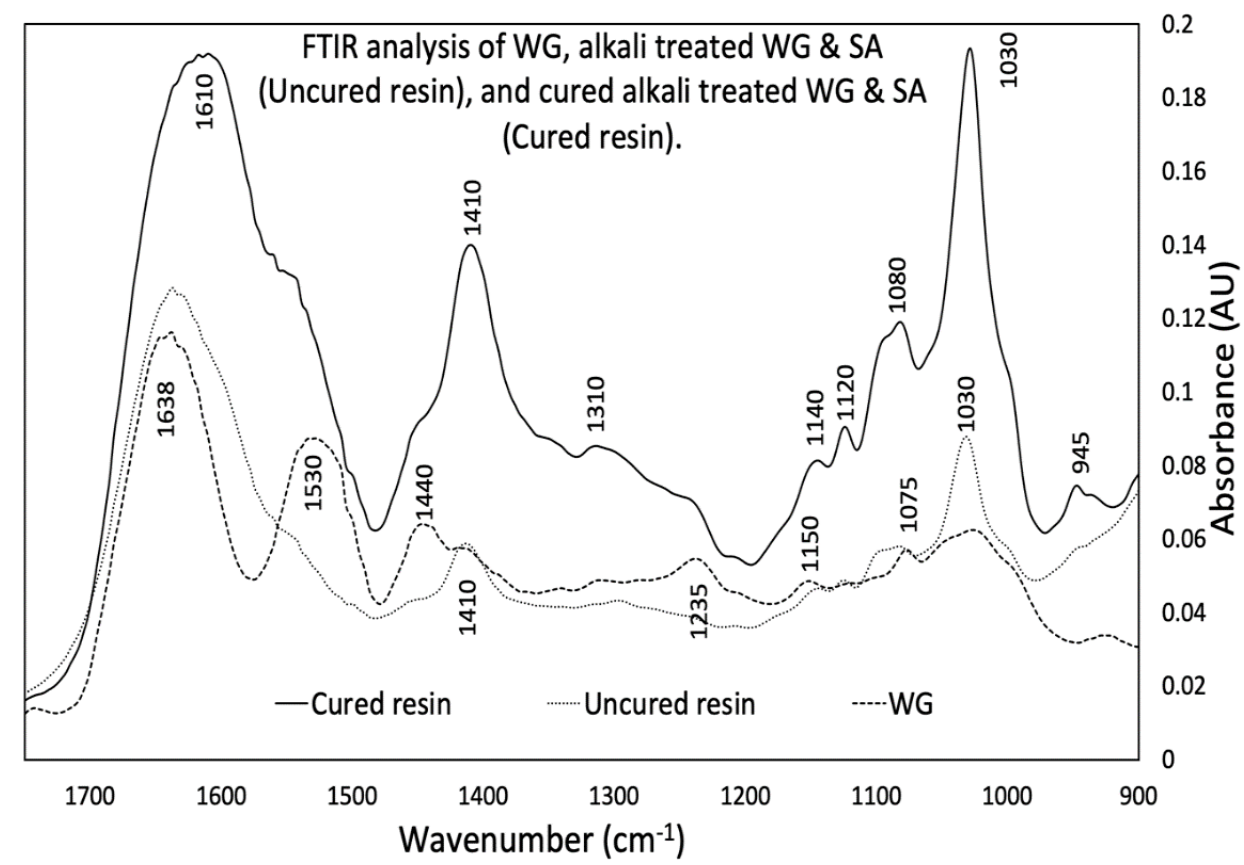

Fig. 9. FTIR analysis of wheat gluten and the alkali-treated cured and uncured resins

The peak shown in Table 4 at $1638 \mathrm{~cm}^{-1}$ of wheat gluten can be assigned to the stretching frequency of the $\mathrm{C}=\mathrm{O}$ in the amide groups. The stretching $\mathrm{C}=\mathrm{N}, \mathrm{C}=\mathrm{C}, \mathrm{C}-\mathrm{N}$, and $\mathrm{N}-\mathrm{H}$ bending can be seen at $1530 \mathrm{~cm}^{-1}$. The peak disappeared in the uncured resin mixture with sodium alginate and in wheat gluten treated with $\mathrm{NaOH}$ probably due to a partial crosslinking reaction. In addition, the peak at $1440 \mathrm{~cm}^{-1}$, which can be assigned to the C$\mathrm{O}-\mathrm{H}$ bending of wheat gluten, was shifted to $1410 \mathrm{~cm}^{-1}$ when WG and SA were alkalitreated, probably as a result of the formation of $\mathrm{S}=\mathrm{O}$ or sulfone groups. A dramatic increase in the intensity of the peak at $1410 \mathrm{~cm}^{-1}$ can be seen after the samples underwent heat treatment (curing), which produced more sulfone groups. Phosphorus and potassium are 
contained in the fertilizers that are used in winter to enhance the wheat yield and quality. The peaks at 1235,1150 , and $1075 \mathrm{~cm}^{-1}$ exemplify the presence of phosphorus and potassium in wheat gluten (Gaj et al. 2012). The C-O-C stretching of sodium alginate and $\mathrm{S}=\mathrm{O}$ sulfoxide stretchings of the partially bonded sulfoxide, which arise from the crosslinking of the LMW/HMW with sodium alginate, were observed at $1030 \mathrm{~cm}^{-1}$ of the uncured resin curve. Followed by the heat treatment, the intensity of the peak located at $1030 \mathrm{~cm}^{-1}$ of the cured sample increased and the peak also broadened (Fig. 9). This might represent the formation of more $\mathrm{C}-\mathrm{O}-\mathrm{C}$ and $\mathrm{S}=\mathrm{O}$ sulfoxide stretching during the heat treatment via the crosslinking of sodium alginate and sub-units of wheat gluten (as shown by the reaction in Fig. 10).

Table 4. FTIR Assignments for Wheat Gluten and Uncured Resin Mixture

\begin{tabular}{|c|c|c|}
\hline $\begin{array}{c}\text { Wavenumber } \\
\left(\mathrm{cm}^{-1}\right)\end{array}$ & Remarks & Reference \\
\hline 1638 & $\begin{array}{c}\text { Stretching frequency of C=O of amide } \\
\text { group }\end{array}$ & Goel et al. (2017) \\
\hline 1530 & $\begin{array}{c}\text { Stretching C=N, C=C, C-N stretching } \\
\text { and N-H bending }\end{array}$ & $\begin{array}{c}\text { Daniel-da-Silva et al. (2008); } \\
\text { Movasaghi et al. (2008); Kläusler } \\
\text { et al. (2014) }\end{array}$ \\
\hline 1440 & C-O-H bending & Reusch (2013) \\
\hline 1235 & Phosphate vibration, C-O stretching & $\begin{array}{c}\text { Chiriboga et al. (1998); Movasaghi } \\
\text { et al. (2008) }\end{array}$ \\
\hline 1150 & C=O, P=O, P-O-C (P-O-P) asymmetric \\
stretching & $\begin{array}{c}\text { Filip et al. (2008); Movasaghi } \text { et al. } \\
(2008)\end{array}$ \\
\hline 1075 & $\begin{array}{c}\text { Symmetric stretching of } \\
\text { phosphodiesters }\end{array}$ & $\begin{array}{c}\text { Fujioka et al. (2004) } \\
\text { stretching }\end{array}$ \\
\hline 1030 & C-O-C stretching, S=O sulfoxide & $\begin{array}{c}\text { Narain (2010); Santiago-Medina et } \\
\text { al. (2017) }\end{array}$ \\
\hline
\end{tabular}

Table 5. FTIR Assignments for Cured Resin Mixture

\begin{tabular}{|c|c|c|}
\hline $\begin{array}{c}\text { Wavenumber } \\
\left(\mathrm{cm}^{-1}\right)\end{array}$ & Remarks & Reference \\
\hline 1610 & Aromatic C=C & Emmanuel et al. (2015) \\
\hline 1410 & Stretching vibration of COO- & Yuan et al. (2017) \\
\hline 1610 & Stretching of C-N bonds & $\begin{array}{c}\text { Jitendra et al. (2015); Ji and } \\
\text { Guo (2018) }\end{array}$ \\
\hline 1140 & C-O-C anti-symmetric stretching, S=O \\
Sulfone & $\begin{array}{c}\text { Zhang et al. (2013); Reusch } \\
(2013)\end{array}$ \\
\hline 1120 & Strong (O-CH ), Mannonse-6-phosphate & $\begin{array}{c}\text { Yoshida et al. (1997); Ooij } \\
(2003)\end{array}$ \\
\hline 1080 & $\begin{array}{c}\text { Symmetric phosphate stretching(P=O } \\
\text { stretching and P-O-C (P-O-P) bonds) }\end{array}$ & $\begin{array}{c}\text { Filip et al. (2008); Movasaghi } \\
\text { et al. (2008) }\end{array}$ \\
\hline 1030 & C-O-C stretching, S=O sulfoxide stretching & $\begin{array}{c}\text { Reusch (2013); Santiago- } \\
\text { Medina et al. (2017) }\end{array}$ \\
\hline 945 & Reusch (2013) \\
\hline
\end{tabular}

The shift of the peak in the uncured sample from 1638 to $1610 \mathrm{~cm}^{-1}$ after curing (Table 5) might represent the formation of clear aromatic $\mathrm{C}=\mathrm{C}$ vibrations (Brudler et al. 1995; Emmanuel et al. 2015). During the curing process, the $\mathrm{C}=\mathrm{O}$ of the amide groups from the wheat gluten proteins crosslinked with the aromatic sodium alginate 
(Satheeshabadu and Mohamed 2015). The peak at $1410 \mathrm{~cm}^{-1}$ in the cured sample might correspond to the reaction of $-\mathrm{COONa}$ from the sodium alginate with the amino acids from the wheat gluten protein. Stretching of $\mathrm{C}-\mathrm{N}$ bonds of the amide is represented by the peak at $1310 \mathrm{~cm}^{-1}$.

The C-O-C anti-symmetric stretching and $\mathrm{S}=\mathrm{O}$ sulfone represented at $1140 \mathrm{~cm}^{-1}$ might be due to the sulfonyl groups formed (Fig. 10). The formation of sulfoxide and sulfonyl bonds revealed that the wheat gluten subunits were separated due to the alkali treatment, and they were probably interacting with ionized sodium alginate.

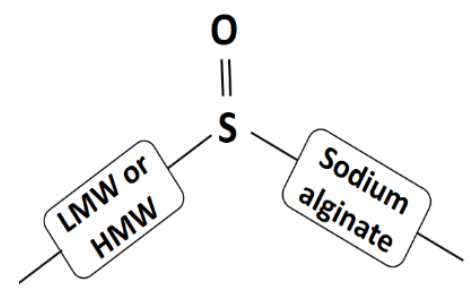

Sulfoxide

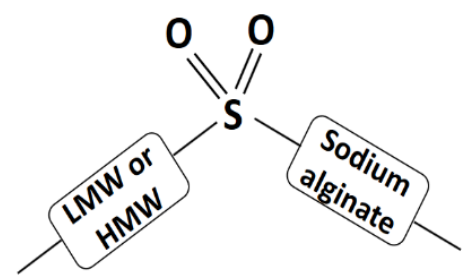

Sulfonyl

Fig. 10. Crosslink reaction between the low or high molecular weight subunits of wheat gluten with sodium alginate

As mentioned above, wheat gluten harvested during winter contains phosphorus and potassium fertilizers (Gaj et al. 2012). The peaks at 1120 and $1080 \mathrm{~cm}^{-1}$ observed in the cured resin indicated the presence of phosphorus in wheat gluten even after curing. Bonding of the hydroxyls with the $-\mathrm{NH}$ groups from the amino acid monomers of wheat gluten can be seen at the newly formed peak at $945 \mathrm{~cm}^{-1}$ in the cured resin. Therefore, the FTIR analysis established that the curing promoted additional peaks that showed the reactivity after heat treatment, enabling functionalization, as expected.

The resin was used to prepare particleboard samples using virgin wood particles and recycled wood-based panel particles of the same size $(1 \mathrm{~mm})$.

The bend strengths and the internal bond values of the virgin and recycled wood samples obtained are presented in Table 6. The IB strength is interrelated with the material density.

Table 6. Mechanical Properties of Particleboard Samples

\begin{tabular}{|c|c|c|c|}
\hline $\begin{array}{c}\text { Type of Wood } \\
\text { Particle }\end{array}$ & $\begin{array}{c}\text { IB Strength } \\
\left(\mathrm{Nm}^{-2}\right)\end{array}$ & $\begin{array}{c}\text { Bending Strength } \\
\left(\mathrm{Nm}^{-2}\right)\end{array}$ & JIS A 5908:2015 \\
\hline Virgin & $0.52 \pm 00$ & $8.08 \pm 0.15$ & Type 8 \\
\hline Recycled & $1.29 \pm 01$ & $18.09 \pm 0.07$ & Type 18 \\
\hline
\end{tabular}

Note: The values of the three different samples used for the testing are reported in Table S1 in the Appendix.

Particleboard samples made using virgin wood particles satisfied the requirements for "type 8 base particleboard decorative particleboard" according to JIS A 5908:2015 (2015), while recycled wood particles satisfied the requirements for type 18. The particleboards made using recycled wood particles had greater than twice the IB value due to its high density and less porous nature. The wood cells of the recycled wood particles were filled with previously used synthetic adhesives. 
The FTIR analysis performed showed the presence of crosslinking in the alkalitreated wheat gluten and sodium alginate resin, whereas the XRD analysis demonstrated the high bonding strength of the resulting panel. The mechanical tests revealed that the sample made with the novel bio-based adhesives can satisfy industrial standards, according to JIS A 5908:2015 (2015). While the type 8 particleboards did not meet the thickness swelling (TS) requirements, the type 18 particleboards did; for this type of particleboard the TS should be less than $12 \%$. The TS achieved in this study for both types of particleboard was $22 \%$.

The use of bentonite as a hardener in the wood adhesive reduced the bending strength and increased the thickness swelling. This corresponded to the brittle nature of bentonite clay as well as its tendency to swell. After conducting the Taguchi experimental design analysis, bentonite was not included in the resin formulation, even though it is known to penetrate through the wood cell walls and make mechanical interlocks.

A comprehensive thermal and rheological analysis, e.g., TGA/DTG, DSC, and DMA, can be done to characterize the resin behavior, but this was out of the scope of this paper. The physical properties, e.g., water-resistance, of the adhesive formulation can be improved during future research.

\section{CONCLUSIONS}

1. The disulfide bonds between the low molecular weight (LMW) and high molecular weight (HMW) proteins subunits break with the addition of $\mathrm{NaOH}$. In an aqueous medium, the $-\mathrm{ONa}$ and $-\mathrm{OH}$ groups in sodium alginate ionize to $\mathrm{O}^{-}, \mathrm{Na}^{+}$, and $\mathrm{H}^{+}$ions. Some of the ionized $\mathrm{O}^{-}$from the sodium alginate form bonds via crosslinking with unbonded disulfide in the low and high molecular weight subunits of wheat gluten (Fig. 10). The rest of the ionized $\mathrm{O}^{-}$bonds with the hydroxyl groups in the cellulose, hemicellulose, and lignins of wood cell walls. The adhesive formulation of alkalitreated wheat gluten (WG) and sodium alginate (SA) in the ratio of 6:1 wt. satisfies the Type 8 of JIS of the particleboard samples made with virgin wood particles.

2. There was improvement in the mechanical and physical properties when the resin was used with recycled wood panel particles, which contained urea-formaldehyde adhesive. This reveals that the proteinaceous wood adhesive can be used to re-manufacture woodbased panels, as proteinaceous adhesives can be blended with synthetic wood adhesives. This can divert the wood-based panel industry from a linear economy to a circular economy. The research was carried out based on the bending strength and internal bond strength as an initial step using an experimental design approach.

\section{ACKNOWLEDGEMENT}

The research was financed by the EcoBulk project (No. 730456-2). The virgin wood materials and industrial know-how were provided by Kastamonu Entegre. The recycled wood particles were provided by the French Institute of Technology for ForestBased and Furniture Sectors. The X-ray diffraction was performed at the University of Basque country, Bilbao, Spain. All the other tests were performed at Cranfield University. 


\section{REFERENCES CITED}

Amini, M. H. M., Hashim, R., and Sulaiman, N. S. (2019). "Formaldehyde-free wood composite fabricated using oil palm starch modified with glutardialdehyde as the binder," International Journal of Chemical Engineering 2019, 1-9. DOI: $10.1155 / 2019 / 5357890$

Bai, Y.-Y., Lei, Y.-H., Shen, X.-J., Luo, J., Yao, C.-L., and Sun, R.-C. (2017). “A facile sodium alginate-based approach to improve the mechanical properties of recycled fibers," Carbohydrate Polymers 174, 610-616. DOI: 10.1016/j.carbpol.2017.06.091

Baishya, P., Nath, D., Begum, P., Deka, R. C., and Maji, T. K. (2018). "Effects of wheat gluten protein on the properties of starch based sustainable wood polymer nanocomposites," European Polymer Journal 100, 137-145. DOI: 10.1016/j.eurpolymj.2017.09.041

Brudler, R., de Groot, H. J. M., van Liemt, W. B. S., Gast, P., Hoff, A. J., Lugtenburg, J., and Gerwert, K. (1995). "FTIR spectroscopy shows weak symmetric hydrogen bonding of the QB carbonyl groups in Rhodobacter sphaeroides $\mathrm{R} 26$ reaction centres," Federation of European Biochemical Societies 370(1-2), 88-92. DOI: 10.1016/0014-5793(95)00805-J

Chiriboga, L., Xie, P., Yee, H., Vigorita, V., Zarou, D. Zakim, D., and Diem, M. (1998). "Infrared spectroscopy of human tissue. I. Differentiation and maturation of epithelial cells in the human cervix," Biospectroscopy 4(1), 47-53. DOI: 10.1002/(SICI)15206343(1998)4:1<47::AID-BSPY5>3.0.CO;2-P

Daniel-da-Silva, A. L., Bordado, J. C. M., and Martín-Martínez, J. M. (2008). “Moisture curing kinetics of isocyanate ended urethane quasi-prepolymers monitored by IR spectroscopy and DSC," Journal of Applied Polymer Science 107(2), 700-709. DOI: 10.1002/app.26453

Day, L., Augustin, M. A., Batey, I. L., and Wrigley, C. W. (2006). "Wheat-gluten uses and industry needs," Trends in Food Science and Technology 17(2), 82-90. DOI: 10.1016/j.tifs.2005.10.003

Draget, K. I., Smidsrød, and Skjåk-Broek, G. (2004). "Alginates from algae,” in: Biopolymers Volume 6: Polysaccharides II: Polysaccharides from Eukaryotes, S. D. Baets, E. Vandamme, and A. Steinbüchel (eds.),Wiley-VCH, Weinheim, Germany, pp. 215-224.

Du, C., Martin, P. A. W., and Nickerson, K. W. (1994). "Comparison of disulfide contents and solubility at alkaline $\mathrm{pH}$ of insecticidal and noninsecticidal Bacillus thuringiensis protein crystals," Applied and Environmental Microbiology 60(10), 3847-3853. DOI: 10.1128/AEM.60.10.3847-3853.1994

El-Wakil, N. A., Abou-Zeid, R. E., Fahmy, Y., and Mohamed, A. Y. (2007). "Modified wheat gluten as a binder in particleboard made from reed," Journal of Applied Polymer Science 106(6), 3592-3599. DOI: 10.1002/app.24499

Emmanuel, V., Odile, B., and Céline, R. (2015). "FTIR spectroscopy of woods: A new approach to study the weathering of the carving face of a sculpture," Spectrochimica Acta Part A: Molecular and Biomolecular Spectroscopy 136(Part C), 1255-1259. DOI: 10.1016/j.saa.2014.10.011

Ferdosian, F., Pan, Z., Gao, G., and Zhao, B. (2017). "Bio-based adhesives and evaluation for wood composites application," Polymers 9(2), 1-29. DOI: 10.3390/polym9020070

Filip, Z., Hermann, S., and Demnerová, K. (2008). "FT-IR spectroscopic characteristics 
of differently cultivated Escherichia coli," Czech Journal of Food Sciences 26(6), 458-463. DOI: 10.17221/14/2008-CJFS

Florence, T. M. (1980). "Degradation of protein disulphide bonds in dilute alkali," Biochemical Journal 189(3), 507-520. DOI: 10.1042/bj1890507

Foroughi, J., Mirabedini, A., and Warren, H. (2018). "Hydrogels fibers," in: Hydrogels, S. Haider, and A. Haider (ed.), IntechOpen, London, United Kingdom, pp. 121-139.

Fujioka, N., Morimoto, Y., Arai, T., and Kikuchi, M. (2004). "Discrimination between normal and malignant human gastric tissues by Fourier transform infrared spectroscopy," Cancer Detection and Prevention 28(1), 32-36. DOI: 10.1016/j.cdp.2003.11.004

Gaj, R., Górski, D., and Przybył, J. (2012). "Effect of differentiated phosphorus and potassium fertilization on winter wheat yield and quality," Journal of Elementology 18, 55-67. DOI: 10.5601/jelem.2013.18.1.04

Gasik, M. I., Uchitel, A. D., Panchenko, A. N., Khmel, V. V. and Solov'ev, E. D. (2009). "Wear of Lurgi-552 gratings when roasting pellets with alkaline bentonite binder," Steel in Translation 39(1), 28-33. DOI: 10.3103/S0967091209010094

Goel, S., Yadav, H., Sinha, N., Singh, B., Bdikin, I., Rao, D. C., Gopalaiah, K., and Kumar, B. (2017). "An insight into the synthesis, crystal structure, geometrical modelling of crystal morphology, Hirshfeld surface analysis and characterization of $\mathrm{N}$-(4-methylbenzyl)benzamide single crystals," Journal of Applied Crystallography 50(5), 1498-1511. DOI: 10.1107/S1600576717012316

Hemmilä, V., Adamopoulos, S., Karlsson, O., and Kumar, A. (2017). "Development of sustainable bio-adhesives for engineered wood panels - A Review," RSC Advances 7(61), 38604-38630. DOI: 10.1039/C7RA06598A

Homayouni, A., Ehsani, M. R., Azizi, A., Yarmand, M., and Razavi, S. H. (2007). "Effect of lecithin and calcium chloride solution on the microencapsulation process yield of calcium alginate beads," Iranian Polymer Journal 16(9), 597-606.

Ibarra, V. G., Sendón, R., and de Quirós, R.-B. (2016). “Antimicrobial food packaging based on biodegradable materials," in: Antimicrobial Food Packaging, J. BarrosVelázquez (ed.), Academic Press, Cambridge, MA, pp. 363-384.

Jansens, K. J. A., Hong, N. V., Telen, L., Brijs, K., Lagrain, B., Vuure, A. W. V., Acker, K. V., Verpoest, I., Puyvelde, P. V., Goderis, B., et al. (2013a). "Effect of molding conditions and moisture content on the mechanical properties of compression molded glassy, wheat gluten bioplastics," Industrial Crops and Products 44, 480-487. DOI: 10.1016/j.indcrop.2012.10.006

Jansens, K. J. A., Lagrain, B., Brijs, K., Goderis, B., Smet, M. and Delcour, J. A. (2013b). "Impact of acid and alkaline pretreatments on the molecular network of wheat gluten and on the mechanical properties of compression-molded glassy wheat gluten bioplastics," Journal of Agricultural and Food Chemistry 61(39), 9393-9400. DOI: $10.1021 / \mathrm{jf} 403156 \mathrm{c}$

Jansens, K. J. A., Telen, L., Bruyninckx, K., Hong, N. V., Gebremeskel, A. F., Brijs, K., Verpoest, I., Smet, M., Delcour, J. A., and Goderis, B. (2017). "Concepts and experimental protocols towards a molecular level understanding of the mechanical properties of glassy, cross-linked proteins: Application to wheat gluten bioplastics," European Polymer Journal 88, 231-245. DOI: 10.1016/j.eurpolymj.2017.01.031

Javed, K., Umer, A., Ramzan, N., Javed, S. H., and Imran, M. (2015). "Possible production of sodium alginate from naturally grown brown algae in Pakistan," Science International (Lahore) 26(5), 2259-2263. 
Ji, X., and Guo, M. (2018). "Preparation and properties of a chitosan-lignin wood adhesive," International Journal of Adhesion and Adhesives 82, 8-13. DOI: 10.1016/j.ijadhadh.2017.12.005

JIS A 5908:2015 (2015). “Particleboards (foreign standard)," Japanese Industrial Standards, Tokyo, Japan.

Jitendra, K., Shahabuddin, Singh, A., Singh, S. P., Saini, P., Dhawan, S. K., and Gupta, V. (2015). "Highly sensitive chemo-resistive ammonia sensor based on dodecyl benzene sulfonic acid doped polyaniline thin film," Science of Advanced Materials 7(3), 518-525. DOI: 10.1166/sam.2015.2000

Khelifi, D., and Branlard, G. (1992). "The effects of HMW and LMW subunits of glutenin and of gliadins on the technological quality of progeny from four crosses between poor breadmaking quality and strong wheat cultivars," Journal of Cereal Science 16(3), 195-209. DOI: 10.1016/S0733-5210(09)80084-2

Khosravi, S., Nordqvist, P., Khabbaz, F., and Johansson, M. (2011). "Protein-based adhesives for particleboards Effect of application process," Industrial Crops and Products 34(3), 1509-1515. DOI: 10.1016/j.indcrop.2011.05.009

Khosravi, S., Nordqvist, P., Khabbaz, F., Öhman, C., Bjurhager, I., and Johansson, M. (2015). "Wetting and film formation of wheat gluten dispersions applied to wood substrates as particle board adhesives," European Polymer Journal 67, 476-482. DOI: 10.1016/j.eurpolymj.2014.11.034

Kläusler, O., Bergmeier, W., Karbach, A., Meckel, W., Mayer, E., Clauß, S., and Niemz, P. (2014). "Influence of N,N-dimethylformamide on one component moisture-curing polyurethane wood adhesives," International Journal of Adhesion and Adhesives 55, 69-76. DOI: 10.1016/j.ijadhadh.2014.07.019

Lagel, M. C., Pizzi, A., Redl, A., and Al-Marzouki, F. M. (2015). "Phenol-wheat proteinformaldehyde thermoset wood adhesives," European Journal of Wood and Wood Products 73, 439-448. DOI: 10.1007/s00107-015-0904-2

Lamacchia, C., Camarca, A., Picascia, S., Luccia, A. D., and Gianfrani, C. (2014). "Cereal-based gluten-free food: How to reconcile nutritional and technological properties of wheat proteins with safety for celiac disease patients," Nutrients 6(2), 575-590. DOI: 10.3390/nu6020575

Langstraat, T. D., Jansens, K. J. A., Delcour, J. A., Puyvelde, P. A., and Goderis, B. (2015). "Controlling wheat gluten cross-linking for high temperature processing," Industrial Crops and Products 72, 119-124. DOI: 10.1016/j.indcrop.2014.11.058

Lei, H., Pizzi, A., Navarrete, P., Rigolet, S., Redl, A., and Wagner, A. (2010). "Gluten protein adhesives for wood panels," Journal of Adhesion Science and Technology 24(8-10), 1583-1596. DOI: 10.1163/016942410X500963

Liu, C., Zhang, Y., Li, X., Luo, J., Gao, Q., and Li, J. (2017). “A high performance bioadhesive derived from soy protein isolate and condensed tannins," RSC Advances 7(34), 21226-21233. DOI: 10.1039/C7RA01210A

Mathias, J.-D., Grédiac, M., and Michaud, P. (2016). "Bio-based adhesives," in: Biopolymers and Biotech Admixtures for Eco-Efficient Construction Materials, F. Pacheco-Torgal, V. Ivanov, N. Karak, and H. Jonkers (ed.), Woodhead Publishing, Cambridge, United Kingdom, pp. 369-385.

Movasaghi, Z., Rehman, S., and Rehman, I. u. (2008). "Fourier transform infrared (FTIR) spectroscopy of biological tissues," Applied Spectroscopy Reviews 43(2), 134-179. DOI: 10.1080/05704920701829043

Nataraj, D., Sakkara, S., HN, M., and Reddy, N. (2018). "Properties and applications of 
citric acid crosslinked banana fibre-wheat gluten films," Industrial Crops and Products 124, 265-272. DOI: 10.1016/j.indcrop.2018.07.076

Naumann, A., Peddireddi, S., Kües, U., and Polle, A. (2007). "Fourier transform infrared microscopy in wood analysis," in: Wood Production, Wood Technology and Biotechnological Impacts, U. Kües (ed.), Universitätsverlag Göttingen, Göttingen, Germany, pp. 179-196. DOI: 10.17875/gup2007-262

Nayar, S., and Bott, K. (2014). "Current status of global cultivated seaweed production and markets," World Aquaculture 45, 32-37.

Nordqvist, P., Johansson, E., Khabbaz, F., and Malmström, E. (2013). "Characterization of hydrolyzed or heat treated wheat gluten by SE-HPLC and ${ }^{13} \mathrm{C}$ NMR: Correlation with wood bonding performance," Industrial Crops and Products 51, 51-61. DOI: 10.1016/j.indcrop.2013.08.057

Nordqvist, P., Lawther, M., Malmström, E., and Khabbaz, F. (2012). “Adhesive properties of wheat gluten after enzymatic hydrolysis or heat treatment - A comparative study," Industrial Crops and Products. 38, 139-145. DOI:

10.1016/j.indcrop.2012.01.021

Nordqvist, P., Khabbaz, F., and Malmström, E. (2010). "Comparing bond strength and water resistance of alkali-modified soy protein isolate and wheat gluten adhesives," International Journal of Adhesion and Adhesives 30(2), 72-79. DOI: 10.1016/j.ijadhadh.2009.09.002

Ooij, W. J. V. (2003). "Spectroscopic techniques in adhesive bonding," in: Handbook of Adhesive Technology Second Edition, Revised and Expanded, A. Pizzi, and K. L. Mittal (ed.), Marcel Dekker, Inc., New York, NY, pp. 380-428.

Pawar, S. N., and Edgar, K. J. (2012). "Alginate derivatization: A review of chemistry, properties and applications," Biomaterials 33(11), 3279-3305. DOI:

10.1016/j.biomaterials.2012.01.007

Reusch, W. (2013). "Infrared spectroscopy," (https://www2.chemistry.msu.edu/faculty/reusch/VirtTxtJml/Spectrpy/InfraRed/infrar ed.htm), Accessed March 2, 2021.

Salem, M. S. M., and Böhm, M. (2013). "Understanding of formaldehyde emissions from solid wood: An overview," BioResources, 8(3), 4775-4790. DOI: 10.15376/biores.8.3.4775-4790

Santiago-Medina, F. J., Pizzi, A., Basso, M. C., Delmotte, L., and Abdalla, S. (2017). "Polycondensation resins by lignin reaction with (poly) amines," Journal of Renewable Materials 5(5), 388-399. DOI: 10.7569/JRM.2017.634142

Satheeshabadu, B. K., and Mohamed, I. (2015). "Synthesis and characterization of sodium alginate conjugate and study of effect of conjugation on drug release from matrix tablet," Indian J. Pharm. Sci. 77(5), 579-85. DOI: 10.4103/0250-474x.169045.

Schalk, K., Lexhaller, B., Koehler, P., and Scherf, K. A. (2017). "Isolation and characterization of gluten protein types from wheat, rye, barley and oats for use as reference materials," PLoS ONE 12(2), 1-20. DOI: 10.1371/journal.pone.0172819

Shewry, P. R., Popineau, Y., Lafiandra, D., and Belton, P. (2000). "Wheat glutenin subunits and dough elasticity: Findings of the EUROWHEAT project," Trends in Food Science and Technology 11(12), 433-441. DOI: 10.1016/S09242244(01)00035-8

Somord, K., Tawichai, N., and Soykeabkaew, N. (2014). "Bio-based adhesive from wheat gluten," in: Proceedings of the $26^{\text {th }}$ Annual Meeting of the Thai Society for Biotechnology and International Conference, 26-29 November, Chiang Rai, 
Thailand, pp. 92-100.

Wang, J., Wei, Z., Li, L., Bian, K., and Zhao, M. (2009). "Characteristics of enzymatic hydrolysis of thermal-treated wheat gluten," Journal of Cereal Science 50(2), 205209. DOI: $10.1016 /$ j.jcs.2009.05.004

Wieser, H. (2007). "Chemistry of gluten proteins," Food Microbiology 24(2), 115-119. DOI: $10.1016 / \mathrm{j} . \mathrm{fm} .2006 .07 .004$

World Health Organization (2004). Monographs on the Evaluation of Carcinogenic Risk to Humans: Volume 88: Formaldehyde, 2-Butoxyethanol and 1-tert-Butoxypropan-2$o l$, International Agency for Research on Cancer, Lyon, France, pp. 1-478.

Yoshida, S., Miyazaki, M., Sakai, K., Takeshita, M., Yuasa, S., Sato, A., Kobayashi, T., Watanabe, S., and Okuyama, H. (1997). "Fourier transform infrared spectroscopic analysis of rat brain microsomal membranes modified by dietary fatty acids: Possible correlation with altered learning behavior," Biospectroscopy 3(4), 281-290. DOI: 10.1002/(SICI)1520-6343(1997)3:4<281::AID-BSPY3>3.0.CO;2-7

Young, R. A., Fujita, M., and River, B. H. (1985). "New approaches to wood bonding A base-activated lignin adhesive system," Wood Science and Technology 19(4), 363381.

Yuan, C., Chen, M., Luo, J., Li, X., Gao, Q., and Li, J. (2017). “A novel water-based process produces eco-friendly bio-adhesive made from green cross-linked soybean soluble polysaccharide and soy protein," Carbohydrate Polymers 169, 417-425. DOI: 10.1016/j.carbpol.2017.04.058

Zhang, J., Song, F., Tao, J., Zhang, Z., and Shi, S. Q. (2018). "Research progress on formaldehyde emission of wood-based panel," International Journal of Polymer Science 2018, 1-8. DOI: 10.1155/2018/9349721

Zhang, Z. P., Rong, M. Z., Zhang, M. Q., and Yuan, C. (2013). "Alkoxyamine with reduced homolysis temperature and its application in repeated autonomous selfhealing of stiff polymers," Polymer Chemistry 4(17), 4648-4654. DOI: $10.1039 / \mathrm{c} 3$ py00679d

Article submitted: February 17, 2021; Peer review completed: March 28, 2021; Revised version received: September 8, 2021; Accepted October 7, 2021; Published: October 11, 2021.

DOI: 10.15376/biores.16.4.7916-7934 


\section{APPENDIX}

Table S1. Mechanical and Physical Properties of Particleboard Samples Made by Using Virgin Wood Particles and Recycled Wood Particles

\begin{tabular}{|c|c|c|c|c|c|c|}
\hline \multirow[b]{2}{*}{ Sample number } & \multicolumn{3}{|c|}{$\begin{array}{l}\text { Particleboard made with } \\
\text { virgin wood particles }\end{array}$} & \multicolumn{3}{|c|}{$\begin{array}{l}\text { Particleboard made with } \\
\text { recycled wood particles }\end{array}$} \\
\hline & 1 & 2 & 3 & 1 & 2 & 3 \\
\hline Length $(\mathrm{mm})$ & 200.00 & 200.00 & 200.00 & 200.00 & 200.00 & 200.00 \\
\hline Width (mm) & 49.03 & 49.34 & 50.06 & 49.67 & 50.31 & 49.82 \\
\hline Thickness $(\mathrm{mm})$ & 10.10 & 9.87 & 10.05 & 9.67 & 9.87 & 10.19 \\
\hline Span (mm) & 150.00 & 150.00 & 150.00 & 150.00 & 150.00 & 150.00 \\
\hline Failure load $(\mathrm{N})$ & 180.00 & 178.00 & 175.50 & 376.45 & 392.70 & 414.00 \\
\hline MOR $\left(\mathrm{N} / \mathrm{mm}^{2}\right)$ & 8.10 & 8.33 & 7.81 & 18.24 & 18.03 & 18.01 \\
\hline Average MOR $\left(\mathrm{N} / \mathrm{mm}^{2}\right)$ & 8.08 & \pm & 0.15 & 18.09 & \pm & 0.07 \\
\hline $\mathrm{P} 1(10 \%$ of $\mathrm{F}$ load) & 18.00 & 17.80 & 17.55 & 37.65 & 39.27 & 41.40 \\
\hline P2 (40\% of F load) & 72.00 & 71.20 & 70.20 & 150.58 & 157.08 & 165.60 \\
\hline P1 value & 18.02 & 17.81 & 17.54 & 37.64 & \begin{tabular}{|l|}
39.29 \\
\end{tabular} & 41.42 \\
\hline P2 value & 72.01 & 71.22 & 70.21 & 150.58 & 157.09 & 165.61 \\
\hline d1 value & 1.44 & 1.45 & 1.42 & 1.38 & 2.18 & 2.10 \\
\hline d2 value & 1.88 & 1.90 & 1.84 & 2.03 & 2.82 & 2.73 \\
\hline MOE $\left(\mathrm{N} / \mathrm{mm}^{2}\right)$ & 2049.50 & 2110.93 & 2082.28 & 3264.18 & 3210.50 & 3155.25 \\
\hline Average MOE (N/mm²) & 2080.90 & \pm & 17.75 & 3209.98 & \pm & 31.45 \\
\hline Length $(\mathrm{mm})$ & 49.93 & 49.97 & 50.05 & 50.02 & 49.97 & 49.96 \\
\hline Width $(\mathrm{mm})$ & 49.03 & 49.34 & 50.06 & 49.67 & 50.31 & 49.82 \\
\hline Thickness $(\mathrm{mm})$ & 10.10 & 9.87 & 10.05 & 9.67 & 9.87 & 10.19 \\
\hline weight $(\mathrm{g})$ & 18.01 & 17.93 & 18.43 & 22.00 & 22.45 & 23.51 \\
\hline Density $\left(\mathrm{kg} / \mathrm{m}^{3}\right)$ & 728.40 & 736.81 & 731.92 & 915.71 & 904.76 & 926.94 \\
\hline $\begin{array}{l}\text { Average density } \\
\left(\mathrm{kg} / \mathrm{m}^{3}\right)\end{array}$ & 732.38 & \pm & 2.44 & 915.81 & \pm & 6.40 \\
\hline Failure load $(\mathrm{N})$ & 1275.54 & 1284.90 & 1292.76 & 3255.00 & 3189.00 & 3212.00 \\
\hline IB $\left(\mathrm{N} / \mathrm{mm}^{2}\right)$ & 0.52 & 0.52 & 0.52 & 1.31 & 1.27 & 1.29 \\
\hline Average IB (N/mm²) & 0.52 & \pm & 0.00 & 1.29 & \pm & 0.01 \\
\hline Mass before dry (g) & 19.78 & 19.93 & 19.35 & 21.65 & 21.00 & 20.73 \\
\hline Mass after dry (g) & 18.23 & 18.44 & 17.73 & 19.36 & 18.88 & 18.49 \\
\hline Moisture content (\%) & $9 \%$ & $8 \%$ & $9 \%$ & $12 \%$ & $11 \%$ & $12 \%$ \\
\hline Average MC (\%) & $9 \%$ & \pm & $0 \%$ & $12 \%$ & \pm & $0 \%$ \\
\hline Thickness before $(\mathrm{mm})$ & 10.10 & 9.87 & 10.05 & 9.67 & 9.87 & 10.19 \\
\hline Thickness after $(\mathrm{mm})$ & 11.27 & 11.16 & 11.22 & 10.58 & 10.65 & 11.20 \\
\hline Thickness swelling (\%) & $12 \%$ & $13 \%$ & $12 \%$ & $9 \%$ & $8 \%$ & $10 \%$ \\
\hline Average TS (\%) & $12 \%$ & \pm & $0 \%$ & $9 \%$ & \pm & $1 \%$ \\
\hline
\end{tabular}

